\title{
Seoul Declaration on the Korea-Africa Forum November 2006
}

- We, the participants of "The 1st KoreaAfrica Forum" held in Seoul on 7 to 9 November 2006, acknowledge that the Forum laid the foundation for a framework of friendship, partnership and cooperation between Korea and the African countries.

- We recognize that the African countries, equipped with the potential for full growth and development, and dynamic Korea need to bolster inter-regional cooperation as a way to respond to the fast-changing global environment, including the increasing interdependence of nations in this rapidly globalizing world.
- Having in mind the importance of solidarity as a fundamental value to international relations in the 21st century, we reaffirm the importance of implementing the Millennium Development Goals(MDGs) adopted in 2000 and call on all the development partners to actively contribute to the efforts of the African countries in achieving their goals.

- In this context, we highly appreciate “Korea's Initiative for Africa's Development" declared by President Roh Moo-hyun during his visit to African countries in March 2006 and the Korean Government's announcement to increase its aid budget including the 
tripling of Official Development Assistance for African countries by 2008.

We welcome the Korean Government's commitment to assist the African countries in human resource development by inviting 1,000 trainees within the following three years and share its development experience with Africa.

- We also welcome the Korean Government's commitment to provide full support for the African countries in pursuing objectives of the New Partnership for Africa's Development (NEPAD) such as poverty reduction, and in addressing problems in key priority areas including water, agriculture, health, education, science and technology ICT, and good governance.

We also recognize that collaborative programs should proceed from Africa's own initiative for its development, along with cooperation of international partners such as Korea.
- We acknowledge the need to establish long-term and mutually-beneficial relationship by promoting trade and investment between Korea and Africa.

- We also acknowledge that the KoreaAfrica Forum will not only establish a close economic partnership but also play a vital role in promoting mutual understanding among people from various cultures and reaffirm our commitment to fostering closer ties in the areas of mutual interest.

- We agreed that the Korea-Africa Forum should be held regularly to serve as a mechanism for substantive cooperation.

Seoul, Republic of Korea November 8, 2006 
국제개발협력동향 2006년 제4호

$\begin{array}{lrl}\text { 발 } & \text { 행 } & \text { 2006년 12월 } \\ \text { 편집·발행처 } & \text { 한국국제협력단 정책연구실 } \\ \text { 주 } & \text { 소 } & \text { 서울시 종로구 연건동 128 } \\ \text { 전 } & \text { 화 } & (02) 740-5114 \\ \text { 팩 } & \text { 스 } & \text { (02)744-1092 } \\ \text { 홈 페 이 지 } & \text { www.koica.go.kr } \\ \text { 인 } & \text { 쇄 } & \text { 마스터-원 TEL.(02)2272-5002(代) }\end{array}$

